\title{
11. 長骨断層撮影における核陰影の影響について
}

\author{
大阪大学医学部附屈病院中央故射缐部 \\ 三春友吉 中西省三 \\ (Tomoyoshi Miharu) (Shozo Nakanishi)
}

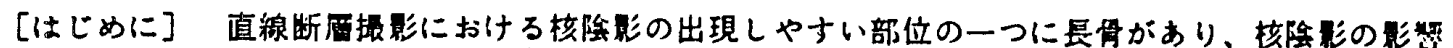

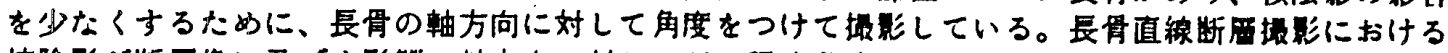

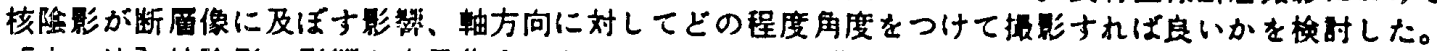

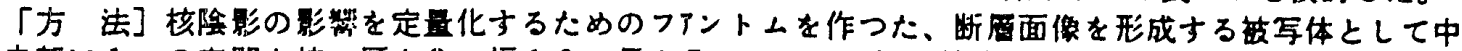
央部に $1 \mathrm{~mm}$ の空間を持つ厚さ3 mm幅 $10 \mathrm{~mm}$ 長さ5 $\mathrm{cm}$ のルルミ板、核㓌影を形成する障害物として厚さ

$5 \mathrm{~mm}$ 幅 $10 \mathrm{~mm}$ 長 $5 \mathrm{c}$ 町了ルミ板を、被写体の上 $0.2 .5 .10 \mathrm{~mm}$ に保持し、被军体の長粙方向に村

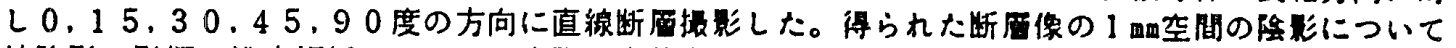

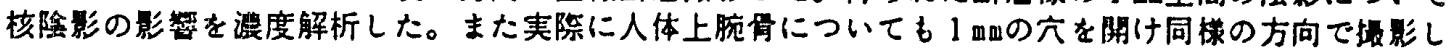

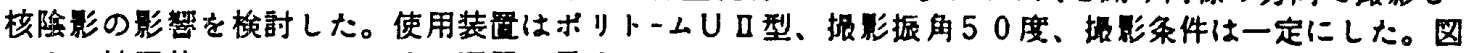
一1は被写体フォントムとその配置を示す。

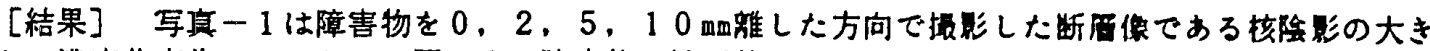

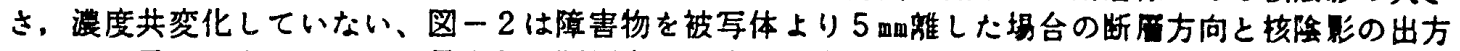

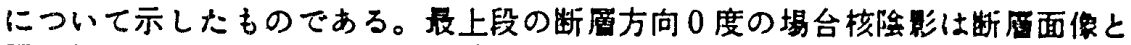
同じ幅に出現しています。この核陰影の幅を $100 \%$ とした場台断居方向に よつて変わり，45度では5 4 \%まで成少している。たた核陵影部分の泿度は

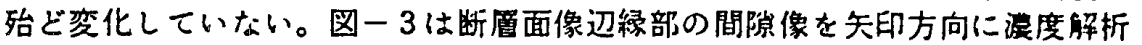
したもので断層方向により核㓌影の影㥿が大きく異なり浱度はかなり変化して いる。30度の方向ではこの部分に核㓌影は含まれず，0度方向に比べ 0.21の差が見られた。写真一2はフアントム及び長骨の単純像。0、30 度方向断層像を示す。 0 度よりも30 度方向像が辺縁部は晃やすいなつている。 [まとめ] 長骨直楾断層撮影では断層方向によつて核㓌影の出方が大きく 異なる.中央部の像は核陰影によつて余り変化しないが，辺縁部は㧡㓌影の 出方に大きく影漓され，溚度もかなり変化した，辺縁部は断層方向 30 度の 場合が最も見やすかつた。

[考察］核陰影の出方を定量化するために単純なフアントんを用いたが 実際には核陵影を作る障害物は断層面と連続的に分布しまた形状も連続的に 変化している。単純ボケ像や干涉㓌影, 核陵影は複台的にも出現するため 核侄影の影㗜を特定するのは難しい，また断層面の像もいろいろな方向に 分布するため注目する断層面像に上つて最適撮影方向は変わろ可能性がある。

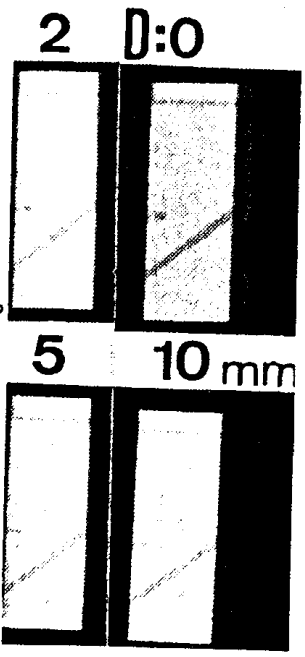

写直 -1

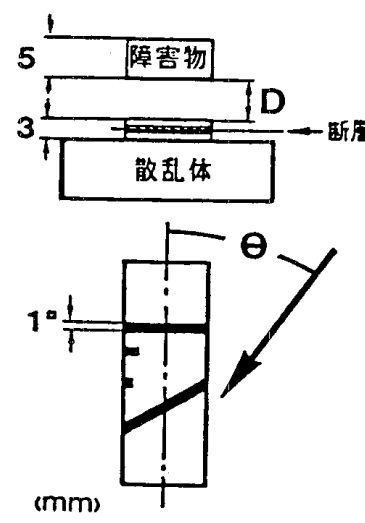

図-1

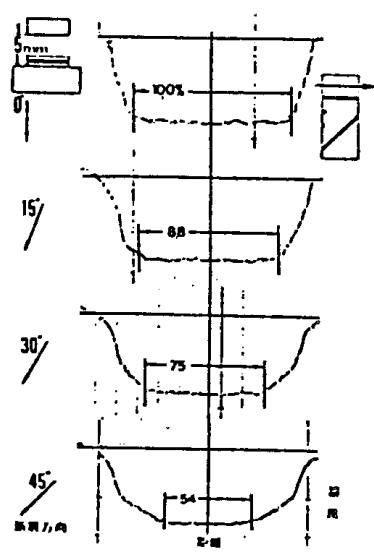

図-2

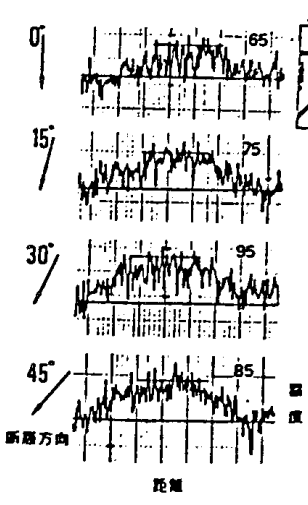

図-3

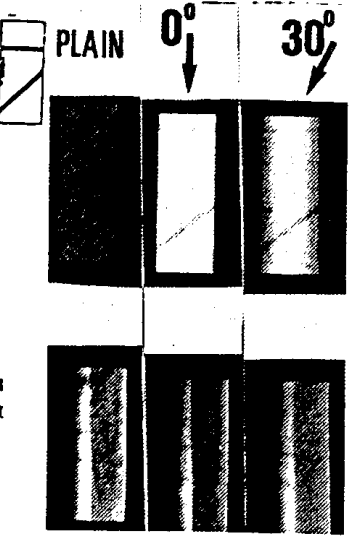

写真 -2 